\title{
Synthesis of new metoclopramide derivatives and in vitro evaluation of their human cholinesterases protection against Chlorpyrifos
}

\author{
Yasser Fakri Mustafa*, Ahmed A.J. Mahmood**, Islam Tarik Qasim*** \\ Departments of* Pharmaceutical Sciences, ** Clinical Pharmacy, \\ *** Pharmacology. College of Pharmacy, University of Mosul, Mosul, Iraq

$\frac{\text { Received }}{4.4 .2011} \quad \frac{\text { Accepted }}{3 .{ }^{\vee} .2011}$

ABSTRACT

Objective: The purpose of this study was to synthesize three new derivatives of metoclopramide by diazotization and replacement reactions and then to quantify in vitro their protection effects on blood cholinesterases using chlorpyrifos as a potent inhibitor.

methods: The three new metoclopramide derivatives were synthesized via Sandmeyer reaction, the chemical structures of these derivatives were identified by physico-chemical and spectroscopic (U.V. and FTIR) techniques.

Results and conclusion: The results of in vitro evaluation of their human cholinesterases inhibition and protection against chlorpyrifos indicated that the $(\mathrm{OH})$ functional group binds to cholinesterase (ChE) at the same organophosphorous (OP) binding site and shows some competition and protection ability but not to a significant degree, while the $(\mathrm{Cl}$ and $\mathrm{I})$ functional groups bind to the $\mathrm{ChE}$ at site differs from $\mathrm{OP}$ binding site, as well as the (I) functional group has more selectivity for enzyme moiety and binds more strongly than the $(\mathrm{Cl})$ group, so that shows more $\mathrm{ChE}$ inhibiting ability.

Keywords: metoclopramide, Sandmeyer reaction, cholinesterase, chlorpyrifos.

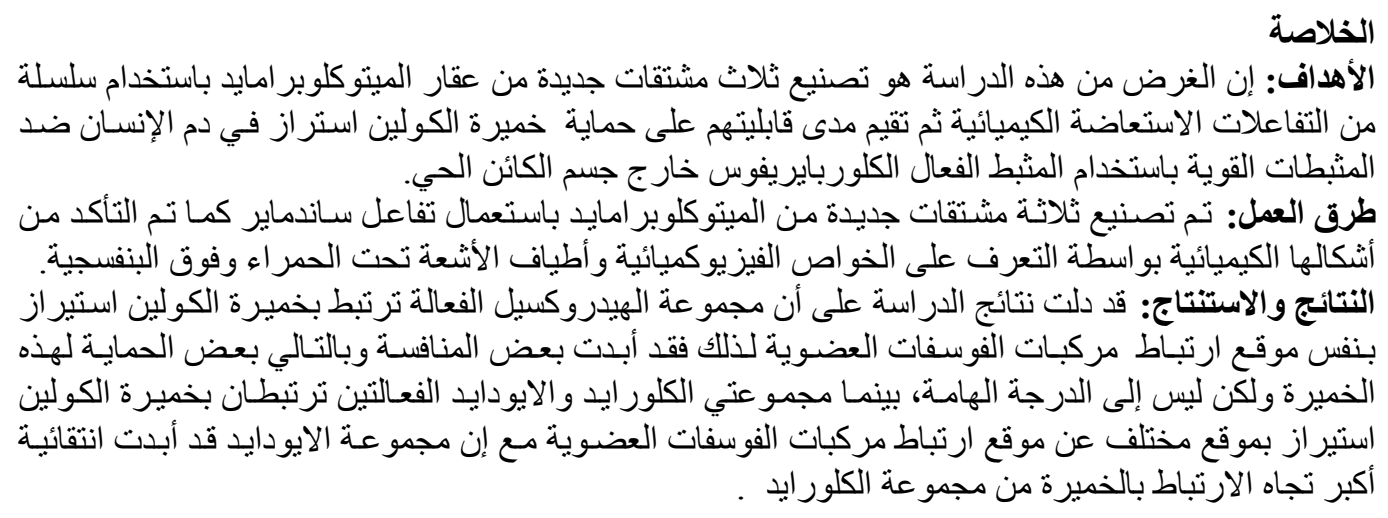

$\mathbf{M}$ etoclopramide (methoxychloroprocainamide, MCP) is a dopamine $\mathrm{D}_{2}$-receptor antagonist benzamide derivative developed in the 1960s and also has an agonistic effect at serotonin receptors (5-HT4) ${ }^{1}$. Clinically, MCP is used owing to its prokinetic and antiemetic effects, these effects of MCP may be enhanced due to inhibition of the cholinesterase $\mathrm{e}^{2,3}$. The drug is weakly inhibiting cholinesterase activity both in vivo and in vitro $^{4}$ and is reported to prevent organophosphorous compounds (OP) poisoning in man (using in vitro system) ${ }^{5}$ and in animals both in vitro and in vivo ${ }^{6}$. The protective action of metoclopramide is thought to be a 
competition for the active site of enzyme with the more potent OP, thus metoclopramide may reduce the toxicity of different OP compounds as dichlorvos and daizinon ${ }^{7}$.

Organophosphorous compounds are serine esterase and protease inhibitors widely used in agriculture as insecticides, in industry and technology as softening agents and additives, and some of them are declared as chemical warfare agents ${ }^{8}$. The single most important mechanism of the toxic action of these insecticides in man and animals is the inhibition of cholinesterase (ChE) at the nerve terminals resulting in an accumulation of acetylcholine that subsequently causing a series of muscarinic, nicotinic and central nervous system effects $^{9,10}$.

Chlorpyrifos (phosphorothionic acid $O, \quad O$-diethyl $O$-[3,5,6-trichloro-2pyridyl] ester) is an organophosphorous insecticide which is considered by the U.S. Environmental Protection Agency to be moderately toxic or slightly toxic depending on the formulation ${ }^{11}$.

Weak and reversible inhibitor of cholinesterases, when administered before potent organophosphorous class compound, has the ability to protect a certain extent the enzyme from inhibition $^{12}$. The putative mode of protective action of $\mathrm{MCP}$ is, when administered in excess, a competition for the active site of enzyme with the more potent organophosphate, this protective effect of metoclopramide is thought to be of practical usefulness for the treatment of organophosphate poisoning $^{13}$.

The purpose of this study was to synthesize three new derivatives of MCP by diazotization and replacement reactions and then to quantify in vitro their protection effects on blood cholinesterases using chlorpyrifos as a potent inhibitor.

\section{Materials and methods}

Part I - synthesis of MCP derivatives

The parent compound

(metoclopramide) was supplied from

Ninevah Drug Industry (Iraq). The chemical compounds used in this research were of analytical grade purity and the solvents were purified by distillation prior to use. The melting points were measured using an electrothermal CIA 9300 apparatus, and were reported uncorrected. The IR spectra of the compounds in $\mathrm{KBr}$ pellets were recorded on a Buck 500 scientific FTIR spectrophotometer.

The ultraviolet-visible spectra were obtained via Carrywinn U.V. Varian U.V. - visible spectrophotometer. The chemical structures were drawn by Chemdraw Office 2001 software. Thin-layer chromatography (TLC) was carried out on TLC plastic sheets silica gel $60 \mathrm{~F} 5$ pre-coated, $20 \times 20 \mathrm{~cm}$, layer thickness $0.2 \mathrm{~mm}$. The spots on the chromatograms were localized using U.V. light (366 nm) (Whatmann). The solvent system employed for separation composed from methanol:strong ammonia solution (98.5:1.5).

General procedure for the synthesis of diazonium salt solution ${ }^{14}$

Metoclopramide hydrochloride (3.54 g, $10 \mathrm{mmole}$ ) was dissolved in $35 \mathrm{ml}$ of water in a beaker, the resulting solution was cooled by immersing in a bath of crushed ice. The cold solution of sodium nitrite ( $0.83 \mathrm{~g}, 12 \mathrm{mmole})$ in $(12 \mathrm{ml})$ water was placed in a dropping funnel and then added dropwise into the stirred solution of metoclopramide hydrochloride in an ice bath; the reaction temperature was kept below $5^{\circ} \mathrm{C}$ by adding few grams of crushed ice when necessary. After the last addition, the resulting solution was stirred for $5 \mathrm{~min}$ in an ice bath. A drop of the solution diluted with (4 drops) of water was tested with potassium iodide-starch paper; if no immediate 
blue color was obtained at the point of contact with paper, a further $1 \mathrm{ml}$ of sodium nitrite solution was added, and the solution tested again after $5 \mathrm{~min}$. Further adding and testing were continued until an immediate blue color was obtained. Thus, the diazonium salt solution was prepared.

\section{Synthesis of compound $\mathbf{I}^{15}$}

The diazonium salt solution was brought to room temperature and heated in a water bath at $100{ }^{\circ} \mathrm{C}$ for $(15 \mathrm{~min})$ to allow the release of nitrogen gas. Distilled water $(20 \mathrm{ml})$ was added to the mixture and the $\mathrm{pH}$ adjusted to 4 . The solution was kept for $(24 \mathrm{~h})$ at room temperature. The formed precipitate was collected by filtration and purified by crystallization from ethanol-water mixture $(9: 1)$, the compound purity was checked by TLC and its result showed that only a single spot was observed. The physicochemical properties of this compound are listed in Table 1.

\section{Synthesis of compound $\mathrm{II}^{16}$}

Cuprous chloride should be prepared freshly by dissolving $3.5 \mathrm{~g}, 14 \mathrm{mmol}$ of $\mathrm{CuSO}_{4} .5 \mathrm{H}_{2} \mathrm{O}$ and $0.95 \mathrm{~g}, 16 \mathrm{mmol}$ of $\mathrm{NaCl}$ in $13 \mathrm{ml}$ of distilled water in a conical flask with warming on a water bath. A solution of $0.95 \mathrm{~g}, 5 \mathrm{mmol}$ of $\mathrm{Na}_{2} \mathrm{~S}_{2} \mathrm{O}_{5}$ in $10 \mathrm{ml}$ of distilled water was added to the previous hot solution dropwise with shaking. The mixture allowed to stand in an ice bath for 30 min. and filtered off. The filtrated particles washed with a dilute solution $(0.5 \%)$ of $\mathrm{Na}_{2} \mathrm{~S}_{2} \mathrm{O}_{5}$, dissolved in $7 \mathrm{ml}$ of conc $\mathrm{HCl}$ and kept in an ice bath for $30 \mathrm{~min}$. The cuprous chloride solution was added dropwise into the cold diazonium salt solution, stirred at 20 ${ }^{\circ} \mathrm{C}$ for $40 \mathrm{~min}$ and at $70{ }^{\circ} \mathrm{C}$ for $40 \mathrm{~min}$. The resulting mixture was stored overnight at room temperature. The product was filtered under vacuum and purified by crystallization from ethanol, the compound purity was established by TLC and its result showed that only a single spot was observed. The physicochemical properties of this compound are listed in Table 1.

\section{Synthesis of compound III $^{17}$}

$\mathrm{KI}$ (1.66 g, $10 \mathrm{mmol})$ was dissolved in $10 \mathrm{ml}$ water; the resulted solution was cooled to $0{ }^{\circ} \mathrm{C}$ and added dropwise under continuous stirring into a cold diazonium salt solution. The $\mathrm{pH}$ was adjusted to 3.5 and after standing for $12 \mathrm{~h}$ at room temperature, the resulting precipitate was filtered under vacuum and purified by crystallization from an ethanol:water mixture $(8: 2)$, the compound purity was established by TLC and its result showed that only a single spot was observed. The physicochemical properties of this compound are listed in Table 1.<smiles>[X]c1cc(OC)c(C(=O)NCCN(CC)CC)cc1Cl</smiles>

Table 1. Physicochemical properties of the synthesized compounds.

\begin{tabular}{|l|c|c|c|c|c|}
\hline Compound no. & $\mathrm{X}$ & m.p. $\left({ }^{\circ} \mathrm{C}\right)$ & $\%$ yield & $\mathrm{R}_{\mathrm{f}}$ & $\lambda_{\max }$ chloroform (nm) \\
\hline Compound I & $\mathrm{OH}$ & $216-218$ & 78 & 0.56 & 472 \\
\hline Compound II & $\mathrm{Cl}$ & $154-156$ & 55 & 0.34 & 312 \\
\hline Compound III & $\mathrm{I}$ & $106-108$ & 62 & 0.42 & 398 \\
\hline
\end{tabular}

For Metoclopramide: $\mathrm{X}=\mathrm{NH}_{2} ;$ m.p. $=182-184^{\circ} \mathrm{C} ; \mathrm{R}_{\mathrm{f}}=0.47 ; \lambda_{\max }($ chloroform $)=254 \mathrm{~nm}^{18}$ 


\section{Part II - In vitro assay of the ChE protection ability}

The subjects included in this study (male and females, age $30 \pm 10$ years) were apparently healthy with no history of exposure to OP insecticides. Blood samples were collected in the 5 ml EDTA-treated test tubes and then centrifuged by (Centurion, $\mathrm{UK})$ at $3000 \mathrm{rpm}$ for $15 \mathrm{~min}$. The erythrocytes and plasma were pooled and kept on ice for the ChE assay.

\section{Electrometric assay of $\mathrm{ChE}$ activity $^{19-21}$}

The reaction mixture in a $10 \mathrm{ml}$ beaker contained $3 \mathrm{ml}$ of distilled water, 0.2 $\mathrm{ml}$ of plasma or erythrocytes and $3 \mathrm{ml}$ of ( $\mathrm{pH}$ 8.1) barbital-phosphate buffer was prepared and its $\mathrm{pH}(\mathrm{pH} 1)$ was measured with glass electrode using $\mathrm{pH}$ meter (Hanna Instruments, Romania). Then $0.1 \mathrm{ml}$ of aqueous acetylcholine solution (7.5\%) was added and the reaction mixture was incubated at $37{ }^{\circ} \mathrm{C}$ in a water bath (Shaker bath 5BS30, UK) for $20 \mathrm{~min}$. After that, the $\mathrm{pH}$ of reaction mixture $(\mathrm{pH} 2)$ was measured and the enzyme activity was calculated as follows: $\mathrm{ChE}$ activity $(\Delta \mathrm{pH} / 20 \mathrm{~min})=.(\mathrm{pH} 1-$ $\mathrm{pH} 2)-\Delta \mathrm{pH}$ of blank

The blank was without the blood aliquot. The barbital-phosphate buffer solution was prepared from $1.24 \mathrm{~g}$ sodium barbital, $0.163 \mathrm{~g}$ potassium dihydrogen phosphate and $35.07 \mathrm{~g}$ sodium chloride in a one liter of distilled water, the $\mathrm{pH}$ of buffer solution was adjusted to 8.1 with $0.5 \mathrm{~N}$ $\mathrm{HCl}$.

In vitro $\mathrm{ChE}$ inhibition by the MCP derivatives and Chlorpyrifos ${ }^{22}$

Plasma and erythrocyte samples were collected from healthy volunteers and different MCP derivatives concentrations were prepared and then added individually in a volume of 0.1 $\mathrm{ml}$ to the reaction mixture to obtain the final concentrations as follows:
Chlorpyriphos: $4 \mu \mathrm{M}$

Compound I: 200, 100, 75, 50 and 25 $\mu \mathrm{M}$

Compound II: 200, 100, 75, 50 and 25 $\mu \mathrm{M}$

Compound III: 200, 100, 75, 50 and 25 $\mu \mathrm{M}$

The concentrations of chlorpyriphos and the MCP derivatives used in the present study were obtained from preliminary experiments to validate the experimental concentrations. The chlorpyriphos or MCP derivatives were prepared in distilled water and individually added in $0.1 \mathrm{ml}$ to the reaction mixture of the plasma and erythrocytes. The reaction mixture containing chlorpyriphos or $\mathrm{MCP}$ derivatives was incubated at $37^{\circ} \mathrm{C}$ for $10 \mathrm{~min}$. Thereafter, the residual $\mathrm{ChE}$ activity was measured and the $\%$ of enzyme inhibition was calculated as follows:

$\% \mathrm{ChE}$ inhibition $=\left[\mathrm{ChE}_{1}-\mathrm{ChE}_{2}\right] / \mathrm{ChE}_{1}$ $\times 100$

Where $\mathrm{ChE}_{1}$ is the enzyme activity without chlorpyriphos or MCP derivatives (control) while $\mathrm{ChE}_{2}$ is the enzyme activity with chlorpyriphos or MCP derivatives (inhibitor).

In vitro ChE inhibition by the MCP derivatives with Chlorpyriphos in the same sample ${ }^{23}$

The same plasma and erythrocyte samples used in the previous experiment were used here and the same concentrations of MCP derivatives were also applied. $0.1 \mathrm{ml}$ of each derivative concentration mentioned above was added to the reaction mixture which incubated at 37 ${ }^{\circ} \mathrm{C}$ in a water bath for $10 \mathrm{~min}$, then chlorpyriphos diluted with distilled water $(0.1 \mathrm{ml}, 4 \mu \mathrm{M})$ was added after (10 min) from the addition of the MCP derivatives, then the reaction mixture was again incubated at $37^{\circ} \mathrm{C}$ in a water 
bath for $10 \mathrm{~min}$ before the $\mathrm{ChE}$ activity and percentage of enzyme inhibition were calculated as mentioned above.

Data are presented as mean \pm SE and were subjected to analysis of variance followed by the least of significant difference test ${ }^{24}$. Paired Student's t-test was used for the means of two groups $^{25}$. The level of significance was at $\mathrm{P}<0.05$.

\section{Results}

\section{The infrared spectra of the synthesized compounds}

For compound I, the disappearance of medium absorbance band at $3386 \mathrm{~cm}^{-1}$ of the primary amine of metoclopramide and the appearance of medium absorbance band at $3518 \mathrm{~cm}^{-1}$ of free $\mathrm{O}-\mathrm{H}$ group confirmed the formation of compound I. For compound II, the disappearance of medium absorbance band at $3386 \mathrm{~cm}^{-1}$ of the primary amine of metoclopramide and the appearance of strong absorbance bands at 812, 1092 $\mathrm{cm}^{-1}$ of $\mathrm{C}-\mathrm{Cl}$ group confirmed the formation of compound II. For compound III, the disappearance of medium absorbance band at $3386 \mathrm{~cm}^{-1}$ of the primary amine of metoclopramide and the appearance of strong absorbance band at $1211 \mathrm{~cm}^{-1}$ of C-I group confirmed the formation of compound III.

\section{In vitro assay studies}

In vitro inhibition of plasma and erythrocyte $\mathrm{ChE}$ activities by the $\mathrm{ChE}$ inhibitor (Chlorpyriphos $4 \mu \mathrm{M}$ ) and MCP derivatives in different concentrations, and then each one of the MCP derivatives with chlorpyriphos were monitored; the results of these studies are shown in the Tables 2, 3 and 4 .

Table 2. In vitro inhibition of human plasma and erythrocyte cholinesterase activities by compound I and its effect on ChEs inhibition by chlorpyriphos

\begin{tabular}{|c|c|c|c|c|}
\hline \multirow{2}{*}{ Compound I $(\mu \mathrm{M})$} & \multicolumn{2}{|c|}{ Plasma ChE } & \multicolumn{2}{|c|}{ Erythrocyte ChE } \\
\hline & $\Delta \mathrm{pH} / 20 \mathrm{~min}$ & $\%$ Inhibition & $\Delta \mathrm{pH} / 20 \mathrm{~min}$ & $\%$ Inhibition \\
\hline Control $0 \mu \mathrm{M}$ & $1.14 \pm 0.006$ & 0 & $1.001 \pm 0.001$ & 0 \\
\hline chlorpyriphos $4 \mu \mathrm{M}$ & $0.06 \pm 0.012^{\text {* }}$ & 94.70 & $0.95 \pm 0.021^{\text {* }}$ & 21.40 \\
\hline $25 \mu \mathrm{M}^{+}$ & $0.69 \pm 0.006^{\text {* a }}$ & 39.47 & $0.85 \pm 0.012^{\text {* }}$ & 15.42 \\
\hline $\begin{array}{l}25 \mu \mathrm{M} \text { before }{ }^{\ddagger} \\
\text { chlorpyriphos } 4 \mu \mathrm{M}\end{array}$ & $0.09 \pm 0.001^{\text {* }}$ & 92.11 & $0.67 \pm 0.002^{\text {* }}$ & 33.33 \\
\hline $50 \mu \mathrm{M}^{+}$ & 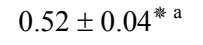 & 54.38 & $0.97 \pm 0.013$ & 3.48 \\
\hline $\begin{array}{l}50 \mu \mathrm{M} \text { before }{ }^{*} \\
\text { chlorpyriphos } 4 \mu \mathrm{M}\end{array}$ & $0.075 \pm 0.015^{*}$ & 93.42 & $1.64 \pm 0.002^{\text {䊑 }}$ & 35.82 \\
\hline $75 \mu \mathrm{M}^{+}$ & $0.52 \pm 0.022^{* a}$ & 54.39 & $0.97 \pm 0.023$ & 3.98 \\
\hline $\begin{array}{l}75 \mu \mathrm{M} \text { before } \\
\text { chlorpyriphos } 4 \mu \mathrm{M}\end{array}$ & $0.095 \pm 0.01^{*}$ & 91.67 & $0.47 \pm 0.002^{\text {糔 } \mathrm{a}}$ & 53.23 \\
\hline $100 \mu \mathrm{M}^{+}$ & $0.39 \pm 0.001^{*} \mathrm{a}$ & 66.23 & $0.96 \pm 0.011$ & 4.98 \\
\hline $\begin{array}{l}100 \mu \mathrm{M} \text { before } \\
\text { chlorpyriphos } 4 \mu \mathrm{M}\end{array}$ & $0.13 \pm 0.052^{\text {* }}$ & 89.04 & $0.73 \pm 0.001$ * & 27.36 \\
\hline $200 \mu \mathrm{M}^{+}$ & $0.24 \pm 0.00^{*}$ & 79.39 & $0.87 \pm 0.002^{\text {糔 }}$ & 13.43 \\
\hline $\begin{array}{l}200 \mu \mathrm{M} \text { before }{ }^{*} \\
\text { chlorpyriphos } 4 \mu \mathrm{M}\end{array}$ & $0.15 \pm 0.052^{*}$ & 87.28 & $0.68 \pm 0.032 *$ & 32.34 \\
\hline
\end{tabular}

$\mathrm{N}=2-3$ / concentration groups.

${ }^{+}$Cholinesterase inhibition was detected after $(10 \mathrm{~min})$ incubation of the sample with compound (I).

$\$$ compound (I)was added to the reaction mixture $(10 \mathrm{~min})$ before the chlorpyriphos addition.

* Significantly different from the respective control (0) group, $\mathrm{P}<0.05^{\mathrm{a}}$ Significantly different from the chlorpyriphos $(4 \mu \mathrm{M}), \mathrm{P}<0.05$ 
Table 2. In vitro inhibition of human plasma and erythrocyte cholinesterase activities by compound I and its effect on ChEs inhibition by chlorpyriphos

\begin{tabular}{|c|c|c|c|c|}
\hline \multirow{2}{*}{ Compound I $(\mu \mathrm{M})$} & \multicolumn{2}{|c|}{ Plasma ChE } & \multicolumn{2}{|c|}{ Erythrocyte ChE } \\
\hline & $\Delta \mathrm{pH} / 20 \mathrm{~min}$ & $\%$ Inhibition & $\Delta \mathrm{pH} / 20 \mathrm{~min}$ & $\%$ Inhibition \\
\hline Control $0 \mu \mathrm{M}$ & $1.14 \pm 0.006$ & 0 & $1.001 \pm 0.001$ & 0 \\
\hline chlorpyriphos $4 \mu \mathrm{M}$ & $0.06 \pm 0.012^{*}$ & 94.70 & $0.95 \pm 0.021^{\text {* }}$ & 21.40 \\
\hline $25 \mu \mathrm{M}^{+}$ & $0.69 \pm 0.006^{\text {*a }}$ & 39.47 & $0.85 \pm 0.012^{*}$ & 15.42 \\
\hline $\begin{array}{l}25 \mu \mathrm{M} \text { before }{ }^{*} \\
\text { chlorpyriphos } 4 \mu \mathrm{M}\end{array}$ & $0.09 \pm 0.001^{*}$ & 92.11 & $0.67 \pm 0.002^{*}$ & 33.33 \\
\hline $50 \mu \mathrm{M}^{+}$ & $0.52 \pm 0.04^{\text {* } \mathrm{a}}$ & 54.38 & $0.97 \pm 0.013$ & 3.48 \\
\hline $\begin{array}{l}50 \mu \mathrm{M} \text { before }{ }^{\ddagger} \\
\text { chlorpyriphos } 4 \mu \mathrm{M}\end{array}$ & $0.075 \pm 0.015^{\text {米 }}$ & 93.42 & $1.64 \pm 0.002^{*}$ & 35.82 \\
\hline $75 \mu \mathrm{M}^{+}$ & $0.52 \pm 0.022^{\text {* } \mathrm{a}}$ & 54.39 & $0.97 \pm 0.023$ & 3.98 \\
\hline $\begin{array}{l}75 \mu \mathrm{M} \text { before }{ }^{\star} \\
\text { chlorpyriphos } 4 \mu \mathrm{M}\end{array}$ & $0.095 \pm 0.01^{*}$ & 91.67 & $0.47 \pm 0.002^{\text {** } \mathrm{a}}$ & 53.23 \\
\hline $100 \mu \mathrm{M}^{+}$ & $0.39 \pm 0.001^{\text {* } \mathrm{a}}$ & 66.23 & $0.96 \pm 0.011$ & 4.98 \\
\hline $\begin{array}{l}100 \mu \mathrm{M} \text { before } \\
\text { chlorpyriphos } 4 \mu \mathrm{M}\end{array}$ & $0.13 \pm 0.052^{*}$ & 89.04 & $0.73 \pm 0.001^{\text {** }}$ & 27.36 \\
\hline $200 \mu \mathrm{M}^{+}$ & $0.24 \pm 0.00^{*}$ & 79.39 & $0.87 \pm 0.002^{*}$ & 13.43 \\
\hline $\begin{array}{l}200 \mu \mathrm{M} \text { before }{ }^{*} \\
\text { chlorpyriphos } 4 \mu \mathrm{M}\end{array}$ & $0.15 \pm 0.052^{\text {* }}$ & 87.28 & $0.68 \pm 0.032^{*}$ & 32.34 \\
\hline
\end{tabular}

$\mathrm{N}=2-3$ / concentration groups.

${ }^{+}$Cholinesterase inhibition was detected after $(10 \mathrm{~min})$ incubation of the sample with compound (I).

* compound (I)was added to the reaction mixture $(10 \mathrm{~min})$ before the chlorpyriphos addition.

* Significantly different from the respective control (0) group, $\mathrm{P}<0.05$

${ }^{a}$ Significantly different from the chlorpyriphos $(4 \mu \mathrm{M}), \mathrm{P}<0.05$ 
Table 3. In vitro inhibition of human plasma and erythrocyte cholinesterase activities by compound II and its effect on ChEs inhibition by chlorpyriphos

\begin{tabular}{|c|c|c|c|c|}
\hline \multirow{2}{*}{ Compound II $(\mu \mathrm{M})$} & \multicolumn{2}{|c|}{ Plasma ChE } & \multicolumn{2}{|c|}{ Erythrocyte ChE } \\
\hline & $\Delta \mathrm{pH} / 20 \mathrm{~min}$ & $\%$ Inhibition & $\Delta \mathrm{pH} / 20 \mathrm{~min}$ & $\%$ Inhibition \\
\hline $0 \mu \mathrm{M}$ & $1.51 \pm 0.01$ & 0 & $1.00 \pm 0.003$ & 0 \\
\hline chlorpyriphos $4 \mu \mathrm{M}$ & $0.06 \pm 0.012^{*}$ & 94.70 & $0.95 \pm 0.021^{\text {* }}$ & 21.40 \\
\hline $25 \mu \mathrm{M}^{+}$ & $1.23 \pm 0.012^{\mathrm{a}}$ & 18.52 & $0.95 \pm 0.016^{*}$ & 5.00 \\
\hline $\begin{array}{l}25 \mu \mathrm{M} \text { before } \\
\text { chlorpyriphos } 4 \mu \mathrm{M}\end{array}$ & $0.00 \pm 0.0^{\text {米 }}$ & 100 & $0.29 \pm 0.006^{* a}$ & 71.27 \\
\hline $50 \mu \mathrm{M}^{+}$ & $1.19 \pm 0.001^{\text {*a }}$ & 21.45 & $0.91 \pm 0.003^{\text {粆 }}$ & 9.50 \\
\hline $\begin{array}{l}50 \mu \mathrm{M} \text { before }{ }^{\ddagger} \\
\text { chlorpyriphos } 4 \mu \mathrm{M}\end{array}$ & $0.00 \pm 0.0^{*}$ & 100 & $0.22 \pm 0.002^{\text {* } \mathrm{a}}$ & 77.8 \\
\hline $75 \mu \mathrm{M}^{+}$ & $1.21 \pm 0.025^{\text {* } \mathrm{a}}$ & 20.13 & $0.91 \pm 0.003^{\text {粦 }}$ & 9.37 \\
\hline $\begin{array}{l}75 \mu \mathrm{M} \text { before } \\
\text { chlorpyriphos } 4 \mu \mathrm{M}\end{array}$ & $0.00 \pm 0.0^{\text {*ै }}$ & 100 & $0.55 \pm 0.012^{\text {粦 } \mathrm{a}}$ & 45.21 \\
\hline $100 \mu \mathrm{M}^{+}$ & $1.22 \pm 0.001^{\mathrm{a}}$ & 19.47 & $0.91 \pm 0.021^{\text {** }}$ & 9.50 \\
\hline $\begin{array}{l}100 \mu \mathrm{M} \text { before } \\
\text { chlorpyriphos } 4 \mu \mathrm{M}\end{array}$ & $0.00 \pm 0.00^{\text {*ै }}$ & 100 & $0.73 \pm 0.01^{\text {** }}$ & 27.5 \\
\hline $200 \mu \mathrm{M}^{+}$ & $1.29 \pm 0.012^{\mathrm{a}}$ & 14.85 & $0.94 \pm 0.001^{\text {粦 }}$ & 6.00 \\
\hline $\begin{array}{l}200 \mu \mathrm{M} \text { before } \\
\text { chlorpyriphos } 4 \mu \mathrm{M}\end{array}$ & $0.00 \pm 0.00^{\text {楼 }}$ & 100 & $0.74 \pm 0.002^{*}$ & 26.50 \\
\hline
\end{tabular}

$\mathrm{N}=2-3$ / concentration groups.

${ }^{+}$Cholinesterase inhibition was detected after $(10 \mathrm{~min})$ incubation of the sample with compound II.

* compound (II) was added to the reaction mixture $(10 \mathrm{~min})$ before the chlorpyriphos addition.

* Significantly different from the respective control (0) group, $\mathrm{P}<0.05$

${ }^{a}$ Significantly different from the chlorpyriphos $(4 \mu \mathrm{M}), \mathrm{P}<0.05$ 
Table 4. In vitro inhibition of human plasma and erythrocyte cholinesterase activities by compound III and its effect on ChEs inhibition by chlorpyriphos

\begin{tabular}{|c|c|c|c|c|}
\hline \multirow{2}{*}{$\begin{array}{l}\text { Compound III } \\
\qquad(\mu \mathrm{M})\end{array}$} & \multicolumn{2}{|c|}{ Plasma ChE } & \multicolumn{2}{|c|}{ Erythrocyte ChE } \\
\hline & $\Delta \mathrm{pH} / 20 \mathrm{~min}$ & $\%$ Inhibition & $\Delta \mathrm{pH} / 20 \mathrm{~min}$ & $\%$ Inhibition \\
\hline Control $0 \mu \mathrm{M}$ & $1.52 \pm 0.007$ & 0 & $1.00 \pm 0.002$ & 0 \\
\hline chlorpyriphos $4 \mu \mathrm{M}$ & $0.06 \pm 0.015^{\text {* }}$ & 94.70 & $0.95 \pm 0.023^{\text {* }}$ & 21.40 \\
\hline $25 \mu \mathrm{M}^{+}$ & $1.06 \pm 0.005^{\text {*a }}$ & 30.09 & $0.09 \pm 0.012$ * $\mathrm{a}$ & 86.05 \\
\hline $\begin{array}{l}25 \mu \mathrm{M} \text { before } \\
\text { chlorpyriphos } 4 \mu \mathrm{M}\end{array}$ & $0.00 \pm 0.0^{*}$ & 100 & $0.14 \pm 0.005^{\text {* } \mathrm{a}}$ & 90.71 \\
\hline $50 \mu \mathrm{M}^{+}$ & $0.99 \pm 0.004^{* a}$ & 34.65 & $0.13 \pm 0.016^{*} \mathrm{a}$ & 87.0 \\
\hline $\begin{array}{l}50 \mu \mathrm{M} \text { before } \\
\text { chlorpyriphos } 4 \mu \mathrm{M}\end{array}$ & $0.00 \pm 0.0^{*}$ & 100 & $0.06 \pm 0.006^{\text {* } \mathrm{a}}$ & 94.0 \\
\hline $75 \mu \mathrm{M}^{+}$ & $0.88 \pm 0.011^{\text {*a } \mathrm{a}}$ & 41.92 & $0.10 \pm 0.008^{*} \mathrm{a}$ & 89.91 \\
\hline $\begin{array}{l}75 \mu \mathrm{M} \text { before } \\
\text { chlorpyriphos } 4 \mu \mathrm{M}\end{array}$ & $0.00 \pm 0.0^{*}$ & 100 & $0.04 \pm 0.013^{*} \mathrm{a}$ & 96.21 \\
\hline $100 \mu \mathrm{M}^{+}$ & $0.82 \pm 0.011^{* \mathrm{a}}$ & 45.88 & $0.09 \pm 0.001^{*} \mathrm{a}$ & 91 \\
\hline $\begin{array}{l}100 \mu \mathrm{M} \text { before } \\
\text { chlorpyriphos } 4 \mu \mathrm{M}\end{array}$ & $\begin{array}{l}0.003 \pm \\
0.002^{\text {粦 }}\end{array}$ & 99.84 & 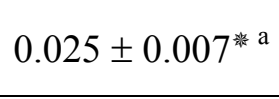 & 97.5 \\
\hline $200 \mu \mathrm{M}^{+}$ & $0.80 \pm 0.001^{* a}$ & 47.19 & $0.11 \pm 0.012^{*} \mathrm{a}$ & 89.0 \\
\hline $\begin{array}{l}200 \mu \mathrm{M} \text { before } \\
\text { chlorpyriphos } 4 \mu \mathrm{M}\end{array}$ & $0.00 \pm 0.0^{*}$ & 100 & $0.04 \pm 0.002^{* \text { a }}$ & 96.0 \\
\hline
\end{tabular}

$\mathrm{N}=2-3$ / concentration groups.

${ }^{+}$Cholinesterase inhibition was detected after (10 min) incubation of the sample with compound (III).

* compound (III) was added to the reaction mixture $(10 \mathrm{~min})$ before the chlorpyriphos addition.

* Significantly different from the respective control group, $\mathrm{P}<0.05$

${ }^{\text {a }}$ Significantly different from the chlorpyriphos $(4 \mu \mathrm{M}), \mathrm{P}<0.05$

\section{Discussion}

The Sandmeyer reaction is a versatile method for replacing the amine group of a primary aromatic amine (e.g. metoclopramide) with a number of different substitutents ${ }^{26}$. The amine is treated with nitrous acid $\left(\mathrm{HNO}_{2}\right)$ under acidic conditions, which produces the diazonium ion. The diazonium ion can then undergo substitution reaction with various reactants, although the substitution can be simplistically viewed as a direct ionic substitution reaction (anion as nucleophile, molecular $\mathrm{N}_{2}$ as a premier leaving group), the actual mechanism is actually more complicated ${ }^{26 .}$ A large number of studies have been devoted to determine the mechanism of Sandmeyer reaction which proceeds with liberation of the diazo nitrogen, 
the most important one depends upon the polarity of the $\mathrm{C}-\mathrm{N}^{+}$bond ${ }^{27}$.

There is a good correlation between $\mathrm{ChE}$ inhibitions in vivo and in vitro, and usually the in vitro $\mathrm{ChE}$ inhibition assists in the clinical interpretation of pesticide intoxication $^{28}$.

In the present study, chlorpyriphos inhibited plasma ChE activity more than erythrocyte $\mathrm{ChE}$, this effect has been reported by others ${ }^{29}$. The weak or reversible $\mathrm{ChE}$ inhibitors can reduce or prevent toxicity of OP when given before $\mathrm{it}^{30}$, such inhibitors as diphenhydramine ${ }^{31,32}$, alpha- 2adrenoceptor metoclopramide 35 agonists ${ }^{33}$, phenothiazines $^{34}$, but when weak ChE inhibitors given after OP, may increase the toxicity of latter compound ${ }^{35}$.

In order to get more protection ability for $\mathrm{ChE}$ by $\mathrm{MCP}$, three new MCP derivatives were synthesized. At different concentrations, these derivatives inhibited $\mathrm{ChE}$ activity at different percentages, depending on their selectivity for the enzyme and the affinity power of the chemical group that modified.

According to Table 2, compound I showed more selectivity for plasma ChE (inhibit plasma ChE more than erythrocyte $\mathrm{ChE}$ ), but still less than that of original compound at all the used concentrations ${ }^{36}$. When compound I used with chlorpyriphos, the selectivity for plasma $\mathrm{ChE}$ provided few protection effect and reduced the inhibition by chlorpyriphos but not statistically significant, but for erythrocyte $\mathrm{ChE}$, compound I showed the same effect of parent compound (i.e. increased significantly the chlorpyriphos inhibition of erythrocyte ChE). These results proposed that the $\mathrm{OH}$ functional group of compound I may be responsible for the selectivity for plasma more than erythrocyte $\mathrm{ChE}$ and may bind to the enzyme moiety at the same binding site of chlorpyriphos resulting in slightly reduction in its ChE inhibiting ability.

According to Table 3, compound II showed different results when compared with compound I and the original compound. The inhibition by compound II alone for both plasma and erythrocyte $\mathrm{ChE}$ was very low but when it combines with chlorpyrifos, the inhibition of both plasma and erythrocyte $\mathrm{ChE}$ increased to higher levels and more than that of the compound I and the original compound for all the concentrations used. These results proposed that the selectivity for enzyme is low (i.e. the functional group responsible for binding to the enzyme moiety has been lost or weakened) and the $\mathrm{Cl}$ functional group of compound II may be responsible for the enhancement of $\mathrm{ChE}$ inhibition by chlorpyriphos because of the difference in the binding sites to enzyme moiety.

According to Table 4, the inhibition of erythrocyte ChE by compound III reached a maximum level and more than that of compounds I, II and the parent compound. The plasma ChE inhibition was low when compared with the compound I and the parent compound, but higher than compound II. When compound III used with chlorpyriphos, the plasma $\mathrm{ChE}$ inhibition was increased while the erythrocyte ChE inhibition was reached a maximum level when compared with all derivatives and the parent compound (Table 2, 3 and 4). These results make an idea of that the functional group of compound III may be responsible for increasing the selectivity of binding to the enzyme moiety and enhancing the $\mathrm{ChE}$ inhibition by chlorpyriphos because of the difference in the binding sites.

\section{Conclusion}

The Change in functional groups of the weak ChE inhibitor by the synthesis of 
new derivatives may clear the picture about how the weak ChE binds to the enzyme moiety and how it competes, decreases or increases the $\mathrm{ChE}$ inhibition of the strong OP compounds. This research proposed that the $\mathrm{OH}$ functional group may bind to the ChE enzyme at the same OP binding site and may show some competition and protection ability but not to a significant degree. While the $\mathrm{Cl}$ and I functional groups may bind to the ChE enzyme at sites differ from OP binding site; the I functional group has more selectivity for enzyme moiety and binds more strongly than the $\mathrm{Cl}$ functional group, so that it shows more ChE inhibiting ability.

\section{References}

1. Narayanan V, Manu RS. Motility disorders of gastrointestinal tract. Indian J pediatrics 2006;73:927930.

2. Graham S, Crossley AW. The characteristics of the Inhibition of serum cholinesterase by metoclopramide. Eur J Clin Pharmacol 1995;48:225-228.

3. Chemnitius JM, Haselmeyer KH, Gonska BD, et al. Indirect parasympathomimetic activity of metoclopramide: reversible inhibition of cholinesterases from human central nervous system and blood. Pharmacol Res 1996;34:6572.

4. Petroianu GA, Hasan MY, Kosanovic M, et al. Metoclopramidee protection of cholinesterase from paraoxon inhibition. Vet Hum Toxicol 2003;45:251-253.

5. Coggon D. Work with pesticides and organophosphate. Dips Occup Med 2002;52:467-470.

6. Petroianu GA, Hasan MY, Nurulain SM, et al. Protective drugs in acute large-dose exposure to organo phosphates: a comparison of metoclopramide and tiapride with pralidoxime in rats. Anesth Analg 2005;100:382-386.

7. Petroianu GA, Hasan MY, Arafat $\mathrm{K}$, et al. Weak inhibitors protect cholinesterases from strong inhibitors (paraoxon): in vitro effect of tiapride. J Appl Toxicol. 2005;25:562-567.

8. Wiener SW, Hoffman RS. Nerve agents: a comprehensive review. J Intensive Care Med 2004;19:2237.

9. Bajgar J. Organophosphates/nerve agent poisoning: mechanism of action, diagnosis, prophylaxis and treatment. Adv Clin Chem 2004;38:151-216.

10. Rusyniak DE, Nanagas KA. Organophosphate poisoning. Semin Neurol 2004;24:197-204.

11. Wendi JD, Gregory C, Ronald GR, et al. Acetyl cholinesterase inhibition in the threeridge mussel (Amblema plicata) by chlorpyrifos: implications for biomonitoring. Ecotoxicol Enviro Saf 2001;49: 9198.

12. Petroianu G, Hassan MY, Kosanovic M, et al. Metoclopramide protection of cholinesterase from paraoxon inhibition. Vet Human Toxicol 2003;45:251-253.

13. Petroianu G, Kuehn F, Thyes C, et al. In vitro protection of plasma cholinesterases by metoclopramide from inhibition by paraoxon. J Appl Toxicol 2003;23:75-79.

14. Mishra HP, Panigrahis S, Pramila $\mathrm{KM}$, et al. Micellar catalysed iododediazoniation reactions. Indian $\mathrm{J}$ Chem 2006;45:2140-2142.

15. .Khoshtariya TE, Matnadze MM, Mirziashvili NT, et al. Synthesis and reductive reactions of 2,3dioxo-2,3dihydrobenzo[b]furo[2,3-f]-,-[2,3$g]-$, and-[3,2-e]indoles. Chem 
Heterocycl Comp 2004;40:14541459.

16. Irena DI, Nadezhda IL, Mark SS. A simple synthesis of angular anthrax-thiophenediones via acetylenic derivatives of anthraquinone. Synthesis 2004;13:2131-2134.

17. Rahmi K, Belma Z, Makbule M, et al. Synthesis of new derivatives of 1-(3-aminophenyl)-4-benzoyl-5phenyl-1H-pyrazole-3-carboxylic acid. J Serb Chem Soc 2010;75:1625-1635.

18. Maurich V, De Amici M, De Micheli C. Synthesis of a metabolite of metoclopramide and its detection in human urine. Farmaco. 1994;49:805-808.

19. Mohammad FK, Faris GA, AlKassim NA. A modified electrometric method for measurement of erythrocyle acetylcholinesterase activity. Vet Hum Toxicol 1997;39:337-339.

20. Ahmed OA, Mohammad FK. A simplified eleclromelric technique for rapid measurement of human blood cholinesterase activity. Internet J Toxicol 2005;2:5 5-58.

21. Mohammad FK, Alias AS, Ahmed OA. Electrometric measurement of plasma, erythrocyte and whole blood cholinesterase activities in healthy human volunteers. J Med Toxicol 2007;3:25:30.

22. Mahmood AA. Interaction of phenothiazines with dichlorvos (cholinesterase inhibitors) in vitro study (master thesis). PA: College of Pharmacy, University of Mosul: 2005

23. Al-Zubaidy MH. Interaction of metoclopramidee with Cholinesterase inhibitors in chicks (master thesis), College of Veterinary Medicine, University of Mosul: 2004.

24. Bruning JL, Kintaz BL. Computational Handbook of
Statistics. Illinois: Scott, Foresman and Co, Glenview: 1977. p:18.

25. Petrie A, Lecture Notes on Medical Statistics. Oxford: Black Well Scientific Publications;1978. p:56.

26. Loloiu G, Loloiu T, Maior O. Synthesis of 1H-pyrrolo[2,3$b]$ phenol xathiin-2,3-dione. Chemistry of Hertro Comp 2004;34:363-366.

27. Vincent LT, Juan MF, Christiaens LE, et al. Synthesis and activity of another seleniated auxin: 2,4dichlorophenyl selenoacetic acid. Plant Growth Regul 2003;40:197-200.

28. Karanth S, Pope C. In vitro inhibition of blood cholinesterase activities from horse, cow and rate by tetrachlorvinphos. Int $\mathbf{J}$ Toxicol 2003;22:429-433.

29. Mahmood AAJ. In vitro inhibition of human blood cholinesterases and protection against chlorpyriphos (organophosphate) by weak anticholinesterase drugs. Iraqi J Pharm 2011;11:18-29.

30. Al-Baggou BK, Mohammad FK. Effects of histamine $\mathrm{H}_{1}$ antagonists on the acute toxicity of physostigmine and neostigmine in mice. Iraqi Vet Sci 1998;11:67-70.

31. Bird SB, Gaspari RJ, Lee WJ, et al. Diphenhydramine as a protective agent in a rat model of acute lethal organophosphate poisoning. Acad Emerg Med 2002;9:1369-1372.

32. Faris GA, Mohammad FK. Prevention and treatment of dichlorvos induced toxicosis in mice by diphenhydramine. Vet Hum Toxicol 1997,39;22-25.

33. Yakoub LK, Mohammad FK. Medetomidine protection against diazinon induced toxicosis in mice. Toxicol Lett 1997;93:1-8.

34. .Petroianu GA, Hasan MY, Nurulain SM, et al. Protective drugs in acute large-dose exposure to organophosphates: 
comparison of metoclopramide and tiapride with pralidoxime in rats. Anesth. Analg.2005;100:382-386.

35. Long PW. Phenothiazine tranquilizers. Internet Mental Health J Appl Toxicol. 2005; 15:5057.
36. Al-Zubaidy MH, Mohammad FK. Metoclopramide protection of diazinon-induced toxicosis in chickens. J Vet Sci 2007;8:249254. 